\title{
Determining the Interaction of the International Portfolio Flows with Exchange Rate Volatility in Developing Countriesa
}

\author{
UtKu AltunÖZb
}

Received: 09.10.2019; Revised: 17.12.2019; Accepted: 10.02.2020

\begin{abstract}
The aim of this study is to examine the effect of the bond portfolio and equity inflows on the exchange rate dynamics for a set of developing countries, including Turkey, Hungary, New Zealand, India, Russia, Poland, Brazil and Argentina over the period 1997:01-2017:12 by using a Markov-switching model. According to the analysis results, the net bond inflows lead to an increase in the likelihood of a high volatility regime in Turkey and Russia and increases the probability of transition from the high volatility regime to the low volatility regime in Hungary. Additionally, the net bond inflows from New Zealand and Poland to the United States (US) rise the possibility of remaining in the low volatility regime. The net equity inflows from Turkey and Poland to the US lead to a rise in the possibility of remaining in the high volatility regime. Besides, the net equity inflows from Brazil and Argentina to the US lead to a decline in the possibility of remaining in the low volatility state. In the light of the empirical results supporting the "return chasing" hypothesis, this paper argues that credit controls on short-term financial inflows could be an effective means in stabilizing the foreign exchange market.
\end{abstract}

JEL codes: F30, F31, G11, G20

Keywords: Exchange rate volatility, Portfolio flows, Markov-switching model, Emerging markets

\section{Introduction}

The liberalization and integration of financial markets led to a rise in cross-border capital flows which are one of the primary factors behind the volatilities in the main currencies. The subject matter is the US dollar, which was comparatively steady in the 1970s but was quite volatile since the early 1980s. According to Hau and Rey (2006), gross cross-border portfolio (stock and bond) flows reached $100 \%$ and $245 \%$ of the gross domestic product (GDP) of the US in 1990s and 2000, respectively, although it was only $4 \%$ in 1975 . However, before the rise again in 2009, they experienced a sharp decline during the collapse of Lehman Brothers in September 2008 (Milesi-Ferretti \& Tille, 2011). Diminishing capital controls, increasing

a The author would like to thanks to two anonymous referees and the editors for their valuable suggestions and contributions.

b Department of Business Administration, Sinop University, Sinop, Turkey. e-mail: utkual@hotmail.com (D) https://orcid.org/0000-0002-0232-3108 
volume of international trade and developments in communication technology accelerate the globalization of financial markets. Significant changes occurred in both the quality and quantity of capital flows towards developing countries since the 1990s. ${ }^{1}$ The resource needs of developing countries and the speculative expectations of investors in developed countries continue to have an impact on short-term capital flows. On the one hand, while international investors change portfolios, the foreign exchange demand that will lead to fluctuations in foreign exchange rates changes. The dynamics of the exchange rate also affect fund investments. Foreign investors tend to diversify their portfolios across different currencies to lower their foreign currency risks. The exchange rate influences the allocation of assets of US investors since the appreciation of the exchange rate provides more gain to its investors in general.

The net portfolio capital flows are a statistic that tracks how much money is being invested in a country by foreigners and the extent to which domestic companies are selling their foreign holdings (Santis \& Lührmann, 2009, 883). The structural determinant of national savings and investment is the demographic profile of a country. A high young population and old-age dependency ratios will bring current account deficit and net capital inflows: a relatively large share of the dependent young and old population in the total population has a relatively lower savings rate (Ando \& Modigliani, 1963). Short-term capital movements, defined as hot money, have a positive impact on both investment and employment by bringing a monetary expansion in addition to national resources which, in turn, increase savings opportunities and raise the level of welfare of the society. Capital inflows are a potential source of higher economic growth, facilitating outsourcing in developing countries. Domestic savings inadequacy, which prevents having a stable growth pattern, especially in developing countries, can be met with capital flows. Considerable fund accumulation brought by shortterm capital movements, rapid hot money inflows and outflows to/from developing countries and significant fluctuations in the country's market may lead to financial crises. Similarly, central banks can use short-term capital as a policy tool in foreign exchange reserves, which causes fluctuation of other variables, causing inefficiency of monetary policy.

The main research question of the paper is to observe the interaction between exchange rate volatility and international bond flows for emerging markets. Thus, validation of the return-chasing hypothesis, which claims that an average equity mutual fund investor tends to buy when past returns are high, is tested. Moreover, the results of the study are intended to be a reference for policymakers and financial regulators.

The next section gives an overview of push and pull factors of capital flows and section 3 provides a brief summary of the elated literature. Sections 4 and 5 explains the data and methodologies utilized and the empirical results, respectively. Section 6 concludes.

\section{Evaluating the Macroeconomic Reasons and Effects of Bond Flows: Pull and Push Factors}

Due to the financial liberalization started in the early 1980s, EMEs have experienced several huge bonds flows that bringing risks and benefits to these economies. The literature on capital flows differentiates factors affecting capital flows (Ylldırım \& İldokuz, 2019, 248)

\footnotetext{
1 Throughout the study, the terms "developing country" and "emerging market economies" (EMEs) are used interchangeably.
} 
to present a useful essential hypothetical context for understanding the driving forces of capital flows. In this context, Fernandez-Arias (1996) defines domestic policies and foreign interest rates as "push" factors and finds that these factors are more dominant on capital flows. On the other hand, Calvo et al. (1996) points out that country-specific "pull" factors such as better country creditworthiness and profitable investment opportunities are more predominant.

Although specific factors have varied in different studies based on its scope, a consensus has emerged on global risk aversion to explain the character of US monetary policy, international liquidity funding (especially in US dollars), and the high synchronicity of monetary flows into emerging markets (Milesi-Ferretti \& Tille, 2011; Cerutti et al., 2019).

When the financial and economic crisis hit the international economy in late 2008, capital flows into EMEs fell abruptly as major outflows from both equity and bonds markets were observed. Nevertheless, after the crisis, global liquidity conditions have directed investors to riskier and higher-yielding assets in EMEs. As a matter of fact, when the risk appetite of investors combined with the relatively strong growth outlooks and higher interest rates of EMEs, these countries witnessed an increase in capital flows especially in the form of bonds flows in 2009 and 2010. According to Erduman \& Kaya (2016), given the past practices of the 1994 Mexican crisis and the 1997 Asian crisis (both were triggered by strong and volatile bonds inflows), the recent wave of capital inflows to the EMEs has increased worries about the potential risks. Therefore, it is underlined that designing appropriate strategies for financial and macroeconomic stability to eliminate undesired outcomes on the capital attracting countries. A good understanding of the determinants of these flows is certainly a prerequisite for the design of such policies. However, this task not only explores the factors that direct capital flows into the EMEs but also how the effects of the flows change over time.

Developing economies were exposed to three key capital inflow periods. The first event began in 1990 and ended in 1997 with the Asian crisis, and left many emerging economies with financial problems resulting from a major capital outflow crisis. Therefore, as the global financial system integrated more rapidly, the EMEs capital account gap became more closely related to the increased trade and financial links with the rest of the affluent world.

As seen from Figure 1, as a result, capital inflows to emerging markets accelerated in 2002. The second wave of capital flows to the EMEs accounted for 80 percent of foreign direct investments, which is revealing a healthier financial account composition (Erduman \& Kaya, 2016, 8). The third movement of capital flows to the EMEs arose as a result of the 2008-2009 global financial crisis, as seen from Figure 2.

When the crisis broke out in the third quarter of 2008, it not only dragged the world financial markets into long-term recessions but also caused a sharp contraction of capital flows to the EMEs.

Theoretical studies draw attention to the effect of state policies and central bank decisions on the exchange rate volatility. Considering the volume of the foreign exchange market in the economy, the stability of the foreign exchange market is extremely important for the course of economic activities. In the floating exchange rate system, in which exchange rates are determined according to market supply and demand, several macroeconomic developments such as variations in domestic and international interest rates, inflation and international capital flows may affect exchange rates (Sağlam \& Başar, 2016, 26). One of the determining factors on exchange rates is the interest rate. Recent studies focusing on the evolution and 


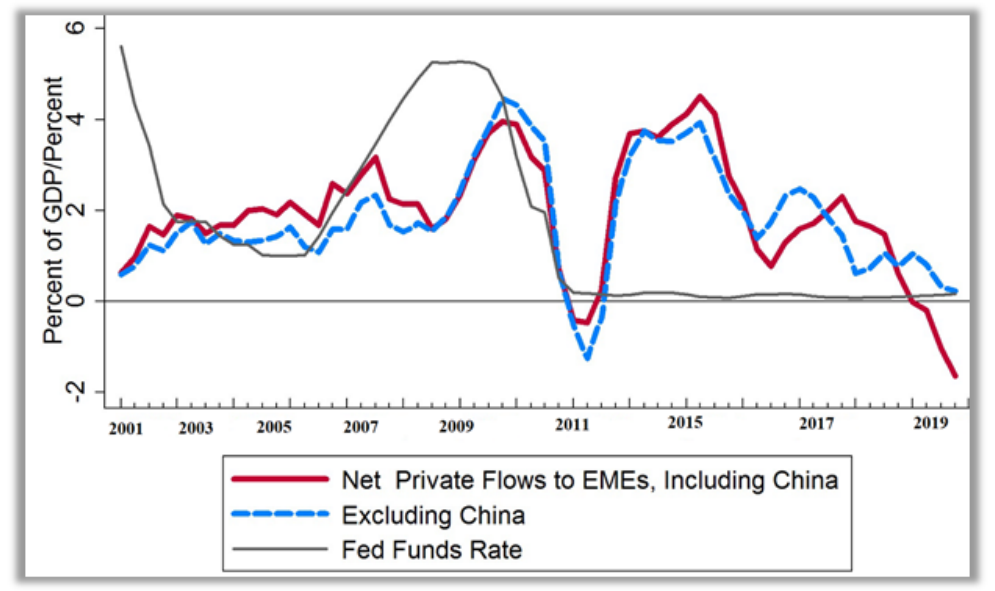

Figure 1: Net Quarterly Private Flows to Emerging Markets

Source: International Monetary Fund (IMF) Balance of Payments annual data.

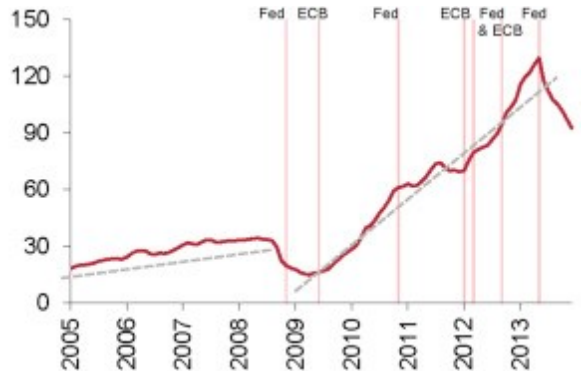

(a) Bond

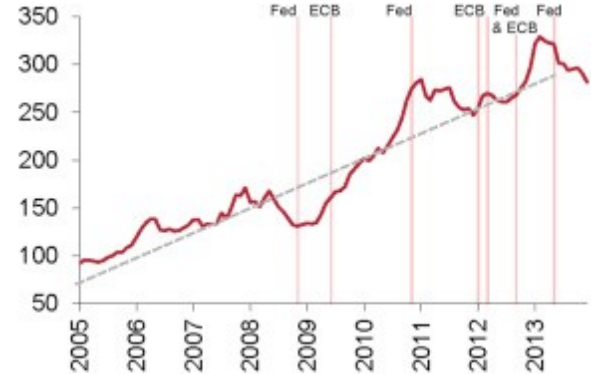

(b) Equity

Figure 2: Bond and Equity Flows to EMEs During the Global Crisis, Stock in billion USD

Source: Erduman \& Kaya $(2016,8)$

Note: Figures are adjusted for exchange rates and prices. Vertical lines show the date of quantitative easing (QE) and long term asset purchase programs of FED and ECB, respectively.

development of monetary models introduce nominal rigidity and imperfect competition in the framework of dynamic stochastic general equilibrium models. In these models, also known as New Keynesian models, changes in monetary settings often create difficult-tounderstand effects on real variables. For this reason, monetary policy can be a potential stabilizer, or it can become a source of economic fluctuations. Therefore, it is an essential area of research to see what consequences the central bank can produce when it changes its policy instrument (the short-term interest rates) in response to changes in macroeconomic conditions (Güler, 2017, 42). Similarly, changes in the exchange rate level and volatility are observed on the days when the treasury will make foreign currency payments. According to Atıs et al. (2019), the existence of exchange rate volatility in a country depends on the flexible exchange rate system. On the other hand, the country's current account deficit, portfolio investments, central bank official reserves and foreign direct investments are among the variables that determine or affect the risk level. 


\section{Literature Review}

The determination of the exchange rate dynamics since the breakdown of the Bretton Woods system has been a major topic in international finance (An \& Wang, 2012; Balke et al., 2013; Tang \& Zhou, 2013). Some papers have studied the character of capital movements in forming the exchange rate (Calvo et al., 1996; Caporale et al., 2017). Given the noteworthy role of the portfolio investments, it is astonishing that only an insignificant number of researchers emphasizes the role of portfolio equilibrium and bond flows in exchange rate movements. Caporale et al. (2017) shows that capital inflows lead to high exchange rate volatility by using monthly bilateral data between the eight Asian countries and the United States. This result shows that stocks and bond flows may have a different effect on the exchange rate dynamics. Raddatz \& Schmukler (2012) indicates that investors and fund managers show cyclical behavior, which causes the spread of crises among countries. Investors tend to invest in the countries affected by the crisis and to increase their investments in parallel with the recovery in these countries. Bonga-Bonga \& Mwamba (2011) measures the level of transmissions of volatility between the capital market and the foreign exchange market in South Africa by using multi-step GARCH models for the weekly data covering JulyW1-OctoberW4 1995. The authors observe that the fluctuations in the stock market were transmitted to the foreign exchange market. This finding can be explained by the important role that international investors play in the capital market in the country.

Omorokunwa \& Ikponmwosa (2014) examines the relationship between exchange rate markets and international investments over the period 1980 and 2011 for the Nigerian Economy. They find that there is a weak impact of volatility in the currency market in the short-run, whereas there are positive and noteworthy effects of volatility in the exchange rate for the long-run. In a study discussing both developing and developed countries, Tudor \& Popescu-Dutaa (2012) tests the relationship between the rate of returns in capital market and the exchange rate volatility for a set of countries including South Africa, Korea, China, India, Russia, Brazil, France, the USA, and the UK over the period 1997-2012. Applying a Granger causality test, they find that the relations between exchange rate volatility and stock markets are noteworthy in Korea. Furthermore, variations in exchange rates affect the returns of equity in Brazil and Russia. Li et al. (2018) examines the international fund flows and the exchange rate dynamics by monthly data for 53 countries. In the result, they demonstrate that there is a solid co-movement between funds flows and bilateral real exchange rates concerning the US Dollar.

Some researchers such as Ahmed et al. (2015) and Mishra et al. (2014) point out that having poor macroeconomic and institutional fundamentals worsen the effects of changes in the country-specific pushing factors for borrowers, while some others including Aizenman et al. (2014) and Eichengreen \& Gupta (2015) have the opposite conclusion. Jabeen \& Ismail (2016) emphasizes the dynamic relations between international bond flows, the exchange rates and their volatilities in Pakistan and the results suggest that the exchange rate volatility does not have a significant effect on the net equity and net bond returns.

Chowdhury (1993) analyzes the dynamic relationship between the exchange rate volatility and exports through a multivariate error correction model. The model is run for each of the G-7 countries using data for the period of 1973-1990. Unlike the previous studies, the author shows that there is a statistically significant negative impact of the exchange rate volatility on the volume of export in all G-7 countries. 
For the Turkish economy, Aslan et al. (2009) investigates the causality relationships between the economic growth, the short-term capital flows, and real exchange rate. The result of econometric analysis supports a unidirectional causality between the economic growth and short-term capital flows, whereas there exists bi-directional causality between real exchange rate and the short-term capital flows. Çiçek (2010) analyzes the effects of mutual price and volatility spread between the foreign exchange, government securities and stock markets for the period of 02.01.2004-30.04.2008 with multivariate EGARCH model. In addition, Johansen cointegration test is used to investigate the long-term interaction between these markets. According to the results, there is a significant price spread effect from the government domestic debt securities and stock markets to the foreign exchange market, while the price spread effect from the foreign exchange market towards the government domestic debt stock and stock markets could not be identified. Erduman \& Kaya (2016) investigates the time changing nature of the determinants of bond flows with a focus on the global financial crisis period and points that the interest rate differential, along with the inflation rate, is the most noteworthy pull factor of bond flows, but the growth rate does not play a significant role. Kılıçarslan (2018) uses the GARCH model and FMOLS method to determine the long-term relationship between the exchange rate volatility and real effective exchange rate volatility for the period 1974-2016 in Turkey. As a result, it is observed that the increase in the national investment expenditures, money supply and trade openness increase real effective exchange rate volatility; but the increase in the foreign direct investments, output level and public expenditures reduce the real effective exchange rate volatility. Ayhan (2019) uses real effective exchange rate (calculated based on the producer price index (PPI)) and portfolio investment variables as indicators of the short-term capital movements and examines the impacts of these variables on the industrial production index by using ARDL, FMOLS, DOLS and Markov Switching models for the period of January 2005-January 2018. According to the results, the real exchange rate has a negative and significant effect on industrial production, but the portfolio investments' effect is not statistically significant. Atış et al. (2019) uses EGARCH and OLS methods to analyze the effects of macroeconomic variables on the real effective exchange rate. They find that the effect of shocks in real effective exchange rate lasts approximately 272 days and negative shocks are more effective on the real effective exchange rate volatility than positive shocks.

\section{Data and Methodology}

In this paper, the effect of the bond and net equity flows on the exchange rate dynamics are examined for eight developing countries: Turkey, Hungary, New Zealand, India, Russia, Poland, Brazil, and Argentina. The dataset covers the period of 1997-2017 and consists of monthly data. Because the USA is the country that has an economic relationship with each developing country, the economic relations between the countries in the analysis and the USA are considered as a bond and net equity flow variable. As the focus of this paper is to investigate the links between bond portfolio flows and net equity and the exchange rate volatility, a regime-switching model which allows the volatility shifts for periods of both high and low exchange rate volatility is constructed. In addition, although a linear model does not tell us anything about the interaction of the portfolio flows and exchange rate volatility, many papers utilize linear models to illustrate the situation (Brooks et al. (2004); Hau \& Rey (2006); Caporale et al. (2017), among others). 
In this study, linear models are used. In the literature on estimating relations between economic and financial variables, it is seen that the interest in non-linear models has an increasing trend. Recent developments in non-linear modeling, as well as linear modeling, and strong tests improved in the literature add special importance and feature to empirical studies. According to Enders (2010), in economic theory, many important time series variables may exhibit non-linear behaviors. However, empirical studies show that linear models are used more than non-linear models. The main reason for this is that linear models are easier to implement, and their results are easier to interpret.

The data for the exchange rates are obtained from the IMF, and the data for bond and net equity flows are obtained from the US Treasury International Capital (TIC) System. As pointed out by Caporale et al. (2017), in spite of some trivial constraints, TIC data is widely used in empirical literature because of the fact that they are still informative about bilateral portfolio investments between the US and the rest of the world. In the analysis, the log changes in the exchange rates are calculated as follow:

$$
R_{t}=\left(\frac{A_{t}}{A_{t-1}}\right) 100
$$

where $A_{t}$ shows the log of the exchange rate at time $t$, and the net bond flows is equal to bond inflows minus bond outflows.

The exchange rates are denominated in the US dollar (USD) per currency. The inflows are measured as the net purchases, and sales of domestic assets (equity and bonds) by foreign residents and the outflows are defined as the net purchases and sales of foreign

Table 1: Descriptive Statistics

\begin{tabular}{|c|c|c|c|c|c|c|}
\hline Country & Variable & Mean & St. Dev. & Skewness & Ex. Kurtosis & Jarque-Bera \\
\hline \multirow{3}{*}{ Turkey } & $r_{t}$ & -0.209 & 1.880 & -2.976 & 25.923 & $7231^{*}$ \\
\hline & $n b f_{t}$ & 0.173 & 1.990 & 1.877 & 17.412 & $3212^{*}$ \\
\hline & $n e f_{t}$ & -0.856 & 2.089 & -2.432 & 14.90 & $1145^{*}$ \\
\hline \multirow{3}{*}{ Hungary } & $r_{t}$ & -0.565 & 5.111 & -4.190 & 39.17 & $120^{*}$ \\
\hline & $n b f_{t}$ & 0.028 & 1.858 & -0.099 & 5.908 & $40^{*}$ \\
\hline & $n e f_{t}$ & -0.399 & 2.112 & -1.011 & 11.00 & $523 *$ \\
\hline \multirow{3}{*}{ New Zealand } & $r_{t}$ & -0.0061 & 0.241 & 0.786 & 7.098 & $300^{*}$ \\
\hline & $n b f_{t}$ & 0.711 & 1.311 & -0.077 & 3.331 & 22 * \\
\hline & $n e f_{t}$ & -0.788 & 1.410 & -0.411 & 3.678 & $18 *$ \\
\hline \multirow{3}{*}{ India } & $r_{t}$ & -0.154 & 4.456 & -6.0985 & 53.08 & $22134^{*}$ \\
\hline & $n b f_{t}$ & 0.431 & 1.890 & -1.678 & 12.78 & $677^{*}$ \\
\hline & $n e f_{t}$ & -0.712 & 1.342 & -0.900 & 4.679 & $44.89 *$ \\
\hline \multirow{3}{*}{ Russia } & $r_{t}$ & -0.687 & 1.113 & -1.809 & 10.90 & $779^{*}$ \\
\hline & $n b f_{t}$ & -0.668 & 10.10 & -6.897 & 45.908 & $18900^{*}$ \\
\hline & $n e f_{t}$ & -0.130 & 1.90 & -6.908 & 77.00 & $70900^{*}$ \\
\hline \multirow{3}{*}{ Poland } & $r_{t}$ & -0.408 & 2.199 & -1.555 & 12.90 & $776^{*}$ \\
\hline & $n b f_{t}$ & -0.034 & 1.887 & -.1 .555 & 7.244 & $290^{*}$ \\
\hline & $n e f_{t}$ & -0.290 & 2.888 & 4.111 & 77.20 & 38111 \\
\hline \multirow{3}{*}{ Brazil } & $r_{t}$ & -0.055 & 3.122 & -1.908 & 32.12 & $3421^{*}$ \\
\hline & $n b f_{t}$ & 0.534 & 5.213 & 11.90 & 190 & 3312 * \\
\hline & $n e f_{t}$ & -0.142 & 1.325 & 0.098 & 2678 & $4211^{*}$ \\
\hline \multirow{3}{*}{ Argentina } & $r_{t}$ & -0.088 & 1.451 & -0.809 & 7.435 & $133^{*}$ \\
\hline & $n b f_{t}$ & 0.278 & 1.564 & -1.891 & 9.45 & $888^{*}$ \\
\hline & $n e f_{t}$ & -0.290 & 1.765 & 0.056 & 7.121 & $321^{*}$ \\
\hline
\end{tabular}


assets (equities and bonds) by domestic residents. For this reason, positive values in Table 1 indicate the net equity and net bond for the US or preferred countries.

In Table 1, negative monthly average changes in the exchange rate indicate that there is a valuation of the USD against all country currencies that are subject to the analysis in the related period. The biggest valuation of the USD occurred against the Russian currency (-0.687), followed by the Hungarian currency (-0.565). At the same time, the smallest valuation of the USD against the analyzed currencies occurred in the currency of New Zealand (-0.0061), and it was followed by the Brazilian (-0.055) and the Argentinian currencies $(-0.088)$. When it is examined from Table 1 , it is seen that the net bond flows are positive for all countries but Russia and Poland. Besides, the net equity flows are negative in all cases. The volatility of the exchange rate is in the range between 0.241 (New Zealand dollar) and 5.111 (Hungarian Forint). The volatility in the net bond flows ranks from the highest for Russia (10.10) to the lowest for New Zealand (1.31). The volatility in the net equity flows ranking from the highest for Poland (2.88) for Poland to the lowest for Brazil (1.325). In conclusion, the Jarque-Bera (JB) test statistics reject the null hypothesis of normality in all cases.

The relationship between the net stock and bond flows and the exchange rate volatility is explored for both high and low volatility periods by using a regime-switching model that permits volatility changes. The specification, by following Caporale et al. (2017), is

$$
r_{t}=\mu\left(s_{t}\right)+\sum_{i=1}^{12} \theta_{i} r_{t-i}+\sigma\left(s_{t}\right) \epsilon_{t}
$$

where $r_{t}$ is the exchange rate changes, $\mu\left(s_{t}\right)$ is the time-varying conditional term, $\epsilon_{t}$ is the error term $\left(\epsilon_{t} \sim N(0,1)\right), s_{t}$ denotes the random variables in $S=(1,2)$ that show the unobserved state of the system at time $t$, and $\sigma\left(s_{t}\right)$ is the volatility in random variables. The vector of the parameters of the means are defined by the autoregressive term $\sum_{i=1}^{12} \theta_{i}$.

In equation $(2), \mu\left(s_{t}\right)$ is supposed to form a Markov chain on $\mathrm{S}$ as follows

$$
\mu\left(s_{t}\right)=\sum_{i=1}^{2} \mu^{(i)} 1
$$

The state switching process follows a transition probability matrix $P^{\prime}=\left[P_{i j}\right]_{2 * 2}$ and

$$
P_{i j}=\operatorname{Pr}\left(s_{t}=j \mid s_{t-1}=i\right), \quad i, j \in S
$$

Sufficient number of autoregressive terms (up to 12 consecutive) are considered to capture $r_{t}$ dynamics. In this step, Caporale et al. (2017) is utilized. For equation (2), the vector of the parameters is defined by autoregressive terms $\sum_{i=1}^{12} \theta_{i}$. Caporale et al. (2017) considers the specification of the net equity and bond flows entered with time-varying transition probabilities and give the regime-shift process. The transition mechanism governing $\mu\left(s_{t}\right)$ is stated as follows.

$$
p_{t}^{k}=\frac{\exp \left(\emptyset_{0}+\vartheta_{1} n b f_{t-1}+\vartheta_{2} n e f_{t-1}\right)}{1+\exp \left(\emptyset_{0}+\vartheta_{1} n b f_{t-1}+\vartheta_{2} n e f_{t-1}\right)}
$$




$$
p_{t}^{f}=\frac{\exp \left(\dot{\omega}_{0}+\dot{\omega}_{1} n b f_{t-1}+\dot{\omega}_{2} n e f_{t-1}\right)}{1+\exp \left(\dot{\omega}_{0}+\dot{\omega}_{1} n b f_{t-1}+\dot{\omega}_{2} n e f_{t-1}\right)}
$$

In equations (5) and (6), nbf $f_{t-1}$ and $n e f_{t-1}$ symbolize the net bond and net equity inflows, respectively. According to Hamilton (1989) and Caporale et al. (2017), positive coefficients $\left(\dot{\omega}_{1}\right.$ and $\left.\dot{\omega}_{2}\right)$ of $p_{t}^{f} / n b f_{t-1}$ and $p_{t}^{f} / n e f_{t-1}$ suggest that an increase in $n b f_{t-1}$ $\left(n e f_{t-1}\right)$ rises the probability of remaining in the state categorized by high exchange rate volatility. In the same way, $\vartheta_{1}>0\left(\vartheta_{2}>0\right)$ suggests that an increase in $n b f_{t-1}\left(n e f_{t-1}\right)$ rises the possibility of remaining in the state categorized by low exchange rate volatility. For evaluation purposes, the next linear model is formulated as follows.

$$
r_{t}=\mu+\sum_{i=1}^{12} \theta_{i} r_{t-k}+\beta_{1} n b f_{t-1}+\beta_{2} n e f_{t-1}+\sigma \epsilon_{t}
$$

\section{Empirical Results}

In the light of this information, results of predicted linear models are seen from Table 2 below.

\begin{tabular}{|c|c|c|c|c|c|c|c|c|}
\hline & Turkey & Hungary & New Zealand & India & Russia & Poland & Brazil & Argentina \\
\hline \multirow[b]{2}{*}{$\mu$} & $-4.122^{* *}$ & -0.445 & -0.223 & $-0.221^{*}$ & $-7.310^{*}$ & -0.501 & -0.466 & $-0.101^{*}$ \\
\hline & $(0.121)$ & $(0.444)$ & $(0.11)$ & $(0.023)$ & $(0.401)$ & $(0.854)$ & $(0.12)$ & $(0.023)$ \\
\hline \multirow{2}{*}{$\beta_{1}$} & -0.011 & -0.08 & $0.321^{* *}$ & 0 & -0.214 & -0.11 & $0.107^{*}$ & 0.301 \\
\hline & $(0.054)$ & $(0.333)$ & $(0.108)$ & $(0)$ & $(0.044)$ & $(0.245)$ & $(0.081)$ & $(0.031)$ \\
\hline \multirow{2}{*}{$\beta_{2}$} & -0.065 & -0.331 & -0.111 & 0.043 & -0.032 & $-0.450^{*}$ & -0.409 & 0.034 \\
\hline & $(0.07)$ & $(0.219)$ & $(0.111)$ & $(0.055)$ & $(0.068)$ & $(0.129)$ & $(0.101)$ & $(0.98)$ \\
\hline \multirow{2}{*}{$\emptyset_{1}$} & $0.181^{*}$ & $0.114^{* *}$ & $0.440^{*}$ & $0.321^{*}$ & $0.175^{*}$ & $0.341^{* *}$ & $0.440^{*}$ & $0.125^{*}$ \\
\hline & $(0.098)$ & $(0.056)$ & $(0.011)$ & $(0.08)$ & $(0.061)$ & $(0.098)$ & $(0.011)$ & $(0.88)$ \\
\hline \multirow{2}{*}{$\emptyset_{2}$} & & & $-0.231^{*}$ & & & & $-0.411^{*}$ & \\
\hline & & & $(0.05)$ & & & & $(0.02)$ & \\
\hline \multirow{2}{*}{$\emptyset_{3}$} & & & $0.033^{* *}$ & & & & $0.142^{* *}$ & \\
\hline & & & $(0.021)$ & & & & & \\
\hline$\sigma$ & 1.891 & 4.9 & 1.98 & 1.211 & 1.775 & 3.819 & 1.714 & 2.624 \\
\hline Log-lik & -312.2 & -578.1 & -440.9 & -399 & -409.1 & -301.1 & -310.5 & -406.1 \\
\hline \multirow{2}{*}{$Q(6)$} & 4.132 & 1.887 & 1.222 & 6.678 & 3.523 & 1.071 & 1.112 & 6.006 \\
\hline & $(0.321)$ & $(0.777)$ & $(0.78)$ & $(0.199)$ & $(0.512)$ & $(0.719)$ & $(0.999)$ & $(0.166)$ \\
\hline \multirow{2}{*}{$Q(12)$} & 7.18 & 11.1 & 11.4 & 10.109 & 7.743 & 8.8 & 18.11 & 24.411 \\
\hline & $(0.656)$ & $(0.099)$ & $(0.444)$ & $(0.321)$ & $(0.421)$ & $(0.012)$ & $(0.39)$ & $(0.321)$ \\
\hline \multirow{2}{*}{$Q^{2}(6)$} & 0.312 & 60.11 & 3.012 & 0.212 & 0.712 & 56.46 & 2.331 & 0.443 \\
\hline & $(0.88)$ & $(0.213)$ & $(0.671)$ & $(0.889)$ & $(0.904)$ & $(0.341)$ & $(0.013)$ & $(0.335)$ \\
\hline \multirow{2}{*}{$Q^{2}(12)$} & 0.444 & 69.9 & 3.231 & 0.444 & 0.381 & 65.5 & 0.267 & 0.312 \\
\hline & $(0.78)$ & (0) & $(0.888)$ & $(0.321)$ & $(0.116)$ & $(0.009)$ & $(0.771)$ & $(0.299)$ \\
\hline
\end{tabular}

Table 2: Results of Estimated Linear Models

Note: Note: ${ }^{*}$ and ${ }^{* *}$ denote the significance levels at $1 \%$ and $5 \%$, respectively. The Ljung-Box test (1978) is represented

by $Q$ and $Q^{2}$. The values in brackets show heteroscedasticity and autocorrelation -consistent standard errors.

The effect of the net bond flows on the exchange rate changes (measured by the coefficient $\beta_{1}$ in Table 2) is not statistically significant for the considered countries except for New Zealand and Brazil. Similarly, the coefficient of the net equity flows $\left(\beta_{2}\right)$ is not statistically significant any of the countries, except for Poland. These results suggest that the simple linear model cannot capture the relationship between exchange rates and flows. 
Table 3: Estimated Markov-Switching Models

\begin{tabular}{|c|c|c|c|c|c|c|c|c|}
\hline & Turkey & Hungary & New Zealand & India & Russia & Poland & Brazil & Argentina \\
\hline \multirow[b]{2}{*}{$\mu_{1}$} & -0.122 & -2.235 & -3.443 & $-1.221^{*}$ & 0.082 & -3.115 & $-4.443^{* *}$ & -0.221 \\
\hline & $(0.121)$ & $(1.444)$ & $(1.11)$ & $(0.023)$ & $(0.121)$ & $(1.444)$ & $(1.11)$ & $(0.123)$ \\
\hline \multirow[b]{2}{*}{$\mu_{2}$} & -0.011 & -0.08 & 0.321 & $0.150^{*}$ & $-0.009^{* *}$ & -0.093 & 0.321 & $0.155^{*}$ \\
\hline & $(0.054)$ & $(0.333)$ & $(0.108)$ & $(0.06)$ & $(0.054)$ & $(0.313)$ & $(0.108)$ & $(0.06)$ \\
\hline \multirow{2}{*}{$\dot{\omega}_{0}$} & $4.065^{*}$ & $3.331^{*}$ & $1 . .111^{*}$ & 0.043 & $4.065^{*}$ & $3.111^{*}$ & $1.101^{* *}$ & $0.123^{*}$ \\
\hline & $(0.07)$ & $(0.219)$ & $(0.111)$ & $(0.055)$ & $(0.07)$ & $(0.265)$ & $(0.432)$ & $(0.875)$ \\
\hline \multirow{2}{*}{$\dot{\omega}_{1}$} & 0.066 & -0.114 & $0.440^{*}$ & -0.321 & 0.421 & $1.114^{*}$ & -0.14 & -0.031 \\
\hline & $(0.198)$ & $(0.056)$ & $(0.011)$ & $(0.08)$ & $(0.698)$ & $(0.056)$ & $(0.011)$ & $(0.08)$ \\
\hline \multirow{2}{*}{$\dot{\omega}_{2}$} & $0.333^{* *}$ & -0.144 & 0.189 & -0.211 & 0.033 & $0.167^{* *}$ & 0.189 & -0.211 \\
\hline & $(0.188)$ & $(0.177)$ & $(0.676)$ & $(0.433)$ & $(0.188)$ & $(0.177)$ & $(0.676)$ & $(0.433)$ \\
\hline \multirow{2}{*}{$\vartheta_{0}$} & $0.412^{*}$ & $2.789^{*}$ & 3.126 & 1.677 & $1.412^{*}$ & $2.289^{*}$ & $5.111^{*}$ & $3.677^{*}$ \\
\hline & $(0.656)$ & $(0.666)$ & $(0.989)$ & $(0.212)$ & $(0.608)$ & $(0.512)$ & $(0.989)$ & $(0.442)$ \\
\hline \multirow{2}{*}{$\vartheta_{1}$} & $0.121^{*}$ & 0.578 & 0.651 & -0.09 & $0.222^{*}$ & 0.105 & $0.600^{* *}$ & 0.077 \\
\hline & $(0.333)$ & $(0.231)$ & $(0.222)$ & $(0.078)$ & $(0.333)$ & $(0.231)$ & $(0.222)$ & $(0.062)$ \\
\hline \multirow{2}{*}{$\vartheta_{2}$} & -0.971 & -0.341 & -1.556 & 0.043 & -0.421 & -0.39 & $-0.056^{*}$ & $-0.703^{*}$ \\
\hline & $(0.441)$ & $(0.133)$ & $(0.665)$ & $(0.111)$ & $(0.121)$ & $(0.19)$ & $(0.665)$ & $(0.111)$ \\
\hline \multirow{2}{*}{$\emptyset_{1}$} & $0.255^{*}$ & $0.244^{*}$ & $0.211^{*}$ & $0.119^{*}$ & $0.215^{*}$ & $0.124^{*}$ & $0.388^{*}$ & $0.110^{*}$ \\
\hline & $(0.055)$ & $(0.033)$ & $(0.054)$ & $(0.028)$ & $(0.415)$ & $(0.009)$ & $(0.011)$ & $(0.88)$ \\
\hline \multirow{2}{*}{$\emptyset_{2}$} & - & - & $-0.125^{*}$ & - & $-0.213^{*}$ & $-0.013^{* *}$ & $-0.125^{*}$ & $-0.111^{*}$ \\
\hline & - & - & $(0.062)$ & - & $(0.022)$ & $(0.088)$ & $(0.062)$ & $(0.022)$ \\
\hline \multirow{2}{*}{$\emptyset_{3}$} & - & - & $0.075^{* *}$ & - & - & - & $0.015^{* *}$ & - \\
\hline & - & - & $(0.011)$ & - & - & - & $(0.011)$ & - \\
\hline \multirow{2}{*}{$\sigma_{1}$} & $3.413^{*}$ & $2.111^{*}$ & $6611^{* *}$ & $5.111^{*}$ & $0.011^{* *}$ & $4.091^{*}$ & $7511^{* *}$ & $3.120^{*}$ \\
\hline & $(0.022)$ & $(0.066)$ & (18.11) & $(1.211)$ & $(0.022)$ & $(0.066)$ & (11.11) & (1.211) \\
\hline \multirow{2}{*}{$\sigma_{2}$} & $0.144^{*}$ & $0.0233^{*}$ & $1.676^{*}$ & $0.177^{*}$ & $0.001^{*}$ & $1.633^{*}$ & $1.326^{*}$ & $0.237^{*}$ \\
\hline & $(0.011)$ & $(0.044)$ & $(0.0111)$ & $(0.011)$ & $(0.001)$ & $(0.044)$ & $(0.018)$ & $(0.011)$ \\
\hline Log-lik & -199.1 & -431.1 & -333.11 & -145.1 & 215.1 & -439.1 & -821.11 & -541.1 \\
\hline \multirow{2}{*}{$Q(6)$} & 9.21 & 10.22 & 4.144 & 2.312 & 7.44 & 12.67 & 4.881 & 2.416 \\
\hline & $(0.111)$ & $(0.066)$ & $(0.658)$ & $(0.011)$ & (0.111) & $(0.096)$ & $(0.448)$ & $(0.019)$ \\
\hline \multirow{2}{*}{$Q(12)$} & 11.18 & 19.11 & 11.98 & 44.14 & 10.09 & 21.01 & 10.967 & 27.14 \\
\hline & $(0.776)$ & $(0.323)$ & $(0.123)$ & $(0.134)$ & $(0.176)$ & $(0.793)$ & $(0.193)$ & $(0.134)$ \\
\hline \multirow{2}{*}{$Q^{2}(6)$} & 1.322 & 23.11 & 44.14 & 11.98 & 1.718 & 83.11 & 44.14 & 16.78 \\
\hline & $(0.111)$ & $(0.022)$ & $(0.134)$ & $(0.123)$ & $(0.901)$ & $(0.122)$ & $(0.134)$ & $(0.545)$ \\
\hline \multirow{2}{*}{$Q^{2}(12)$} & 2.766 & 4.111 & 31.17 & 3.213 & 2.117 & 4.19 & 31.17 & 3.213 \\
\hline & $(0.997)$ & $(0.911)$ & $(0.088)$ & $(0.878)$ & (0.997) & $(0.911)$ & $(0.088)$ & $(0.878)$ \\
\hline
\end{tabular}

The linearity null hypothesis cannot be tested directly against the Markov regimeswitching alternative by using a standard probability ratio (LR) test. Thus, the null hypothesis of multiple equilibria is tested against the alternative hypothesis of linearity by Hansen (1992) by utilizing the normalized likelihood ratio test. The author offers strong evidence in favor of a two-state Markov switching requirement. This process needs the estimation of the likelihood function across a grid of different values for the changeover possibilities and for each state dependent parameter. The standardized probability ratio statistics offer strong evidence for a two-state Markov switching specification. ${ }^{2}$

${ }^{2}$ We also test the existence of a third state, but this is being rejected for all countries. See Table A.1 in Appendix for the test results. 
The next step, the results of the maximum likelihood estimations are provided in Table 3. The results show that the high and low volatility periods are correctly captured with the smoothed probabilities. The time-varying transition probabilities for the net bond $\left(\dot{\omega}_{1}\right)$ and net equity inflows $\left(\dot{\omega}_{2}\right)$ are the direct keys between the two states for selected countries.

The positive predicted value of $\dot{\omega}_{1}$ for Turkey and Russia means that the net bond inflows lead to an increase in the likelihood of a transition to the high volatility regime. Its negative value indicates that it also increases the probability of transition from the high volatility regime to the low volatility regime in Hungary. In the same sense, the statistically significant and positive value of $\vartheta_{1}$ in the case of New Zealand and Poland means that the net bond flows from New Zealand and Poland to the US rise the probability of remaining in the low volatility regime.

When the coefficient $\dot{\omega}_{2}$ is examined, only the estimated values for Turkey and Poland are significant and positive: the net equity flows from Turkey and Poland to the US lead to a rise in the probability of remaining in the high volatility regime. This finding is also supported by the negative sign of the coefficient $\vartheta_{2}$ for Brazil and Argentina: the net equity flows from these countries towards the US lead to a decrease in the probability of remaining in the low volatility state.

\section{Conclusions}

In this paper, the interaction and the relation between the exchange rate and international fund flows are analyzed for the emerging markets. Restrictions on capital have been gradually reduced, the volume of international trade has increased, and developments in communication technologies have accelerated the globalization of financial markets. Capital inflows are a potential source of higher economic growth, facilitating outsourcing in developing countries. The required domestic savings to ensure stable growth, especially in developing countries, are insufficient, and this inability can be met by capital flows.

The interaction between the exchange rate volatility and international bond flows for emerging markets, and the existence of the return-chasing behavior are discussed over the period of 1997-2017. For this purpose, Turkey, Hungary, New Zealand, India, Russia, Poland, Brazil and Argentina are considered as developing/emerging countries. Empirical results show that the net equity and bond inflows significantly affect the transition probabilities from the high to the low volatility regimes for the selected countries.

Net bond flows have no statistically significant effect on exchange rate regime changes for countries outside of New Zealand and Brazil. The effect of net capital inflows on exchange rate changes is not statistically significant for any country other than Poland. This general model suggests that the simple linear model cannot capture the relationship between the exchange rates and the inflows.

These empirical findings can be reasonably interpreted in terms of the "return-chasing" hypothesis and argue that capital controls on bond inflows may be an effective means of balancing the foreign exchange market. Finally, this study reveals that credit controls could be an effective tool for policymakers and financial regulators aimed at stabilizing the foreign exchange market. 


\section{References}

Ahmed, S., Curcuru, S. E., Zlate, A., \& Warnock, F. E. (2015). The Two Components of International Capital Flows [Mimeo].

Aizenman, J., Binici, M., \& Hutchison, M. M. (2014). The Transmission of Federal Reserve Tapering News to Emerging Financial Markets (Working Paper No. 19980). National Bureau of Economic Research (NBER). doi:10.3386/w19980

An, L., \& Wang, J. (2012). Exchange Rate Pass-Through: Evidence Based on Vector Autoregression with Sign Restrictions. Open Economies Review, 23(2), 359-80. doi:10.1007/s11079-010-9195-8

Ando, A., \& Modigliani, F. (1963). The "Life Cycle" Hypothesis of Saving: Aggregate Implications and Tests. American Economic Review, 53(1), 55-84.

Aslan, N., Terzi, N., \& Siampan, E. (2009). Relationships between Short Term Capital Flows, Economic Growth and Real Exchange Rate: The Case of Turkey (in Turkish). Finansal Araştırmalar ve Çalışalar Dergisi, 5(10), 15-32. doi:10.14784/JFRS.2014104497

Atış, A. G., Erer, D., \& Akın, A. (2019). Foreign Exchange Exposure and Its Determinants: The Case of Turkey (in Turkish). Ege Stratejik Araştırmalar Dergisi, 10(2), 43-54. doi:10.18354/esam.569985

Ayhan, F. (2019). An Empirical Research on the Effects of Short-Term Capital Flows and Real Exchange Rate on Economic Growth for Turkey (in Turkish). Ege Stratejik Araştırmalar Dergisi, 14(54), 106-18. doi:10.19168/jyasar.513290

Balke, N. S., Ma, J., \& Wohard, M. E. (2013). The Contribution of Economic Fundamentals to Movements in Exchange Rates. Journal of International Economics, 90(1), 1-16. doi:10.1016/j.jinteco.2012.10.003

Bonga-Bonga, L., \& Mwamba, M. (2011). The Predictability of Stock Market Returns in South Africa: Parametric vs. Non-parametric Methods. South African Journal of Economics, 79(3), 301-11. doi:10.1111/j.1813-6982.2011.01280.x

Brooks, R., Edison, H., Kumar, M. S., \& Sløk, T. (2004). Exchange Rates and Capital Flows. European Financial Management, 10(3), 511-33. doi:10.1111/j.1354-7798.2004.00261.x

Calvo, G. A., Leiderman, L., \& Reinhart, C. M. (1996). Inflows of Capital to Developing Countries in the 1990s. Journal of Economic Perspectives, 10(2), 123-39.

Caporale, G. M., Ali, F. M., Spagnolo, F., \& Spagnolo, N. (2017). International Portfolio Flows and Exchange Rate Volatility in Emerging Asian Markets. Journal of International Money and Finance, 76, 1-15. doi:10.1016/j.jimonfin.2017.03.002 
Cerutti, E., Claessens, S., \& Puy, D. (2019). Push Factors and Capital Flows to Emerging Markets: Why Knowing Your Lender Matters More than Fundamentals. Journal of International Economics, 119, 133-49. doi:10.1016/j.jinteco.2019.04.006

Chowdhury, A. R. (1993). Does Exchange Rate Volatility Depress Trade Flows? Evidence from Error-Correction Models. The Review of Economics and Statistics, 75(4), 700-6. doi: $10.2307 / 2110025$

Eichengreen, B., \& Gupta, P. (2015). Tapering Talk: The Impact of Expectations of Reduced Federal Reserve Security Purchases on Emerging Markets. Emerging Markets Review, 25, 1-15. doi:10.1016/j.ememar.2015.07.002

Enders, W. (2010). Applied Econometric Time Series (3rd ed.). John Wiley \& Sons.

Erduman, Y., \& Kaya, N. (2016). Time Varying Determinants of Bond Flows to Emerging Markets. Central Bank Review, 16(2), 65-72. doi:10.1016/j.cbrev.2016.05.003

Fernandez-Arias, E. (1996). The New Wave of Private Capital Inflows: Push or Pull? Journal of Development Economics, 48(2), 389-418. doi:10.1016/0304-3878(95)00041-0

Güler, A. (2017). Modeling Exchange Rate Volatility under Volatile Economic Conditions: A Dynamic Time Series Analysis for Turkey (in Turkish). International Journal of Academic Value Studie, 3(14), 39-47. doi:10.23929/javs.435

Hamilton, J. D. (1989). A New Approach to the Economic Analysis of Nonstationary Time Series and the Business Cycle. Econometrica, 57(2), 357-84. doi:10.2307/1912559

Hansen, B. E. (1992). The Likelihood Ratio Test under Nonstandard Conditions: Testing the Markov Switching Model of GNP. Journal of Applied Econometrics, 7(S1), S61-S82. doi:10.1002/jae.3950070506

Hau, H., \& Rey, H. (2006). Exchange Rates, Equity Prices, and Capital Flows. The Review of Financial Studies, 19(1), 273-317. doi:10.1093/rfs/hhj008

Çiçek, M. (2010). Interest Rates, Foreign Exchange Rates and Stock Prices in Turkey: Price and Volatility Spillover Effects. Ankara Üniversitesi SBF Dergisi, 65, 1-28. doi:10.1501/SBFder_0000002170

Jabeen, M., \& Ismail, A. (2016). Exchange Rates and International Portfolio Flows: Evidence from Pakistan.

Kılıçarslan, Z. (2018). Determinants of Exchange Rate Volatility: Empirical Evidence for Turkey. Journal of Economics Finance and Accounting, 5(2), 204-13. doi:10.17261/Pressacademia.2018.825

Li, S., de Haan, J., \& Scholtens, B. (2018). Are International Fund Flows Related to Exchange Rate Dynamics? Open Economies Review, 29(1), 31-48. doi:10.1007/s11079017-9469-5 
Milesi-Ferretti, G.-M., \& Tille, C. (2011). The Great Retrenchment: International Capital Flows During the Global Financial Crisis. Economic Policy, 26(66), 289-346. doi:10.1111/j.1468-0327.2011.00263.x

Mishra, P., Moriyama, K., N'Diaye, P. M., \& Nguyen, L. (2014). Impact of Fed Tapering Announcements on Emerging Markets (IMF Working Papers No. 14/109). International Monetary Fund.

Omorokunwa, O., \& Ikponmwosa, N. (2014). Exchange Rate Volatility and Foreign Private Investment in Nigeria. Asian Journal of Business Management, 6(4), 146-54. doi:10.19026/ajbm.6.5157

Raddatz, C., \& Schmukler, S. L. (2012). On the International Transmission of Shocks: Micro-evidence from Mutual Fund Portfolios. Journal of International Economics, 88(2), 357-74. doi:10.1016/j.jinteco.2012.05.006

Sağlam, M., \& Başar, M. (2016). Forecasting Exchange Rate Volatility: The Case of Turkey (in Turkish). KMÜ Sosyal ve Ekonomik Araştırmalar Dergisi, 18(31), 23-29.

Santis, R. A. D., \& Lührmann, M. (2009). On the Determinants of Net International Portfolio Flows: A Global Perspective. Journal of International Money and Finance, 28(5), 880-901. doi:10.1016/j.jimonfin.2008.09.002

Tang, X., \& Zhou, J. (2013). Nonlinear Relationship between the Real Exchange Rate and Economic Fundamentals: Evidence from China and Korea. Journal of International Money and Finance, 32, 304-23. doi:10.1016/j.jimonfin.2012.04.010

Tudor, C., \& Popescu-Dutaa, C. (2012). On the Causal Relationship between Stock Returns and Exchange Rates Changes for 13 Developed and Emerging Markets. Procedia - Social and Behavioral Sciences, 57, 275-82. doi:10.1016/j.sbspro.2012.09.1186

Yıldırım, H. H., \& İldokuz, B. (2019). Uncovered Interest Rate Parity and Determining The Financial Factors Which Pull The Portfolio Investment to Turkey During The 2005-2014 (in Turkish). Ekoist: Journal of Econometrics and Statistics, 14, 247-68.

\section{Appendix: Dimension Test for Markov Switching Model}

Table A.1: Results of Hansen Test

\begin{tabular}{lrr}
\hline Country & Linearity vs. two-states & Two states vs. three-states \\
\hline Turkey & 3.897 & 0.213 \\
Hungary & 3.123 & 0.223 \\
New Zealand & 4.312 & 0.778 \\
India & 3.781 & 0.345 \\
Russia & 3.767 & 0.443 \\
Poland & 4.012 & 0.675 \\
Brazil & 3.213 & 0.88 \\
Argentina & 4.009 & 0.213 \\
\hline Note: Hansen's standardized Likelihood Ratio test (LR) statistics. & The test \\
results for the existence of a third state are also conveyed. &
\end{tabular}

